ing national policy dialogue and participation. If this paper had succeeded in addressing this theme and making concrete proposals, it could have represented a true paradigmatic shift from prior policy papers.

A serious shortcoming of the paper concerns the knowledge base chosen from which lessons of experience are drawn. Of the 152 bibliographic references only 32 (21 percent) are not World Bank publications or publications of Bank staff. In part this gives due credit to the wealth of knowledge on the subject generated internally - including papers commissioned by the Bank on this subject from outside consultants - but it also leads one to question whose experience is meant by the subtitle "The lessons of experience." Given the many positive aspects of this paper it is unfortunate that the authors did not include the significant contributions to the topic that have been made outside the Bank - to name a few of the oversights: Philip Altbach's long line of research on universities and overseas training, Maureen Woodhall'srecent excellent series of publications on student loans in developing countries for the International Institute for Educational Planning, and UNESCO's 1993 policy paper, "Strategies for Change and Development in Higher Education."

In sum, this policy paper is an important contribution to the debate on higher education reform and on education policy reform in general. It departs from prior policy work of the World Bank in a number of important respects, and that gives it the potential of generating controversy and hopefully of supporting a critical examination of past practices in the field.

Few recent World Bank publications have generated so much internal controversy as this policy paper on higher education. To some, the paper does not offer "leadership," and fails to provide sufficient guidance for the Bank to suggest policy reforms to borrowing countries. Other aspects of this controversy focus on the contents of the paper, concerning the role of the state vis à vis the role of the private sector, the kinds of reforms envisioned, and the methods proposed for achieving higher education reform.

At the heart of the debate are two different epistemologies, one that argues that reform can be based on "universal" findings and influenced by pressure from international organizations, another that contends that technical knowledge alone is not sufficient to inform the direction of educational change. The latter position is consistent with what Jiirgen Habermas has called a pragmatic model of the impact of scientific knowledge in policy, in opposition to a decisionistic model-which assumes science is value-neutral - and a technocratic model — which assumes scientific knowledge has intrinsic normative authority (J. Habermas, Toward a Rational Society [London: Heineman, 1971]). The pragmatic model suggests interactions of reciprocal influence between politicians and researchers in a democratic society.
The merits of this paper, beyond its excellent analysis of the problems of higher education, lies in the value it places on democratic processes in negotiating policy and on the more humble, albeit important, role it assigns in that process to research-based knowledge, and consequently to international organizationsthat draw some of their power from access to that knowledge. The debate over the lack of "leadership" provided by the paper suggests that not all are comfortable with this new, more humble role that supports democratic processes of policy negotiation.

This paper matters because it has stimulated discussion on the sources of educational reform. It concerns the role of values in contextualizing findings of research and lessons drawn from experience, and the process that should be followed in designing reform. It is, finally, a debate about national ownership of the process and content of educational change. The debate continues beyond this paper and is perhaps the central source of tension between departments that engage in producing policy papers and operations departments, between the World Bank and governments ofborrowing countries, between governments and other stakeholders in each society.

\section{DIMENSIONS OF HIGHER EDUCATION IN AFRICA}

\author{
Academic Freedom IN Africa \\ Edited by Mahmood Mamdani and Mamadou \\ Diouf. DAKar: CODESRIA, 1994. 370 PP.
}

\section{Paul Tiyambe Zeleza}

Paul Tiyambe Zelezo is Professor of History at Trent University Address: Office of the Principal, Lody Eaton College, Trent University, Pefersborough, Ontario, K9J 788 CANADA Fax: [705] 748-1630

$I^{n}$ $\mathrm{n}$ the last few years, African countries have been rocked by struggles for democracy, whose scope and intensity suggest a fundamental rupturing of the postcolonial order and a profound yearning for a new socioeconomic and political dispensation. Intimately engaged in these broad struggles for the "second independence," African intellectuals have also been waging battles for their own academic freedom, against the social forces and actors that control and constrain the academic research environment and the production of critical ideas - namely, the state, civil society, the institutions dominated by the intellectuals themselves, and foreign donors and Eurocentric academic cultures. This hook, a product of the conference sponsored by the Council for the Development of Social Science Research in Africa (CODESRIA) on academic freedom, held in Kampala in 1990, addresses these issues with urgency, passion, and intelligence, and offers us a rare glimpse into 
the collective psyche of African intellectuals, their historical formation, social contexts, and changing discourses. It is compelling reading.

Besides the brilliant and succinct introduction and conclusion hy Mamdani and Diouf, respectively, the hook is divided into five sections. Authors in the first section reflect on the relations between the state and intellectuals. Except for Hagan's detailed outline of the political economy of university education in independent Ghana, the chapters in this section interrogate the concept and development of academic freedom in general and in the wider African context.Ake's opening chapter underscores the pivotal role played by state capital in the social production of intellectuals and the impact of the fiscal crisis of the 1980s on academic infrastructures and in undermining academic freedom.

But state authoritarianism should not he exaggerated, Ake argues, for the coercive capacities of the postcolonial state are weakened by the limited ideological hegemony enjoyed hy the political class. Intellectualsthemselves shoulder some of the blame for the erosion of academic freedom. Besotted hy opportunism, careerism, parochialism, factionalism, and ideologicalintolerance, intellectuals weakened their collective defense against state assaults, and by defining academic freedom in narrow and elitist terms as a professional right unencumbered by social responsibility, they forfeited popular support. The road to academic freedom must begin with comprehensive self-criticism among the intellectuals themselves, of their practices and values. It needs to he followed, Ki-Zerbo elaborates in the next chapter, by a renewed commitment to social responsibility through the creation ofvibrant and integrated intellectual associations, groups, and communities on national, regional and continental levels, which, in turn, must actively participate in wider struggles for democracy, not in the magisterial role of a revolutionary vanguard, but in "the ministerialone of facilitatingthe free flow of ideas by stripping problems of their mystifying disguises and creating fresh, functional and coherent patterns of perception and conception" (p. 33-34).

Epistemologically,Mafeje argues, the struggle for academic freedom entailsjettisoning Eurocentric theories and paradigms and developing authentic African social science discourses, without falling into the trap of an essentializing cultural revivalism that homogenizes Africa's diverse cultures and histories. This constitutes the subject of section two, where in an extensive and illuminating discussion, Imam and Mama unravel the paradigmatic constraints inherent in all the social science and humanistic disciplines, from psychology and history, to philosophy and economics, which hamper the production of meaningful and relevant knowledge on Africa. These disciplines share a propensity for logical positivism and universalizing Western experiences, and suffer from gender blindness, so that a hierarchization of knowledgehas emerged, leading to the privileging of quantitative over qualitative forms of knowledge, and social facts distilled from Western over African, and male over female, experiences. Compounding and reproducing these biases, the two authors continue, is the unequal access between Africanists and Africans, male and female scholars to research funding, publishing, and citations, and postgraduate training and employment opportunities. Also, the class system of academia breeds conformism and self-censorship among the marginalized scholars, who are usually young, female, and radical. Thu s academic freedom, Mama and Imam believe, is limited through the dominant paradigms used by African intellectuals, and the prevailing practices in their institutions, as mediated by their relationships with external agencies and civil society.

The pressures exerted by external agencies, such as the World Bank, on intellectual production in Africa has been considerable. Outside of the state, the donor agencies are often the only other significant source of financial resources for academic work. The relative freedom that many of them enjoy from domestic political constraints enables them to fund "sensitive"research themes, and they can use their relatively high standing to shield research granteesfrom official harassment and persecution. But these agencies, the papers in the third section suggest, have also contributed to the undermining of academic freedom in Africa. Ali tells a story of how Sudanese economists who disagreed with an International Labour Organisation(ILO) research team on methodological grounds were subsequently shunned by the ILO itself and other donors, including the European Economic Community, which had projects in the Sudan. They decided not to use the Sudanese economists' DevelopmentStudiesResearch Center "tohelp them carry out their research work" (p. 116). And Bako exposes the educational "conditionalities" imposed hy the World Bank on Nigerian universities for a loan of $\$ 120$ million. The Bank recommended a reduction in the number and size of the country's universities, and the privatization of some of their operations, all in the name of increasing efficiency. Most troubling, perhaps, the Bank asked for the centralized supervision over the hooks, journals, and equipment purchased through the loan and the close monitoring of the "adjusted"universities through the Ministry of Education. This provoked widespread resistance from faculty, staff, and students. Interventions by the World Bank in debt-ridden African countries parallels, according to Mittelman, the corporatization of university education in the United States, with its negative implications for academic freedom.

For his part, Mazrui in a typically eclectic survey of the impact of global changes on academic freedom in Africa, observes that the end of the cold war is restricting, not expanding, the global options for academic freedom. 
"As the ideology of pluralism triumphs," he writes, "the diversity ofsystemic options narrows"(p. 121).Mazrui also broaches the issue of language, suggesting that academic freedom in Africa "is devalued by excessive linguistic dependence" (p. 121). This proposition is considered briefly by $M$ afeje and in more detail by Mamdani in section four, for whom this is ultimately a question of the democratization of knowledge, not simply of authenticity. The use of European languages in intellectual discourse among African scholars, outside of North Africa, marks and reproduces the alienation between the intellectuals and civil society, and partly explains the scholars' statist conception of power, irrespective of ideological inclinations and whether or not they are state supporters or opponents, for it is a discourse they share with the political class, not the "masses."

There is a tendency to draw sharp distinctions between the state and civil society, to idealize the latter as a protective and humane refuge from the insatiable and coercive exactions of the state. This dichotomy is false, for the state and civil society interpenetrate and regulate and appropriate each other's functions, and intellectuals, as Farah puts it in her fascinating chapter on civil society and freedom of research in Egypt, "are both state functionaries and the ideologicalinterpreters of civil society" (p. 265). In Egypt the "people" or society proved inimical to academic freedom as the religious ideology of Islam, promoted by successive political regimes as a tool of political legitimation and mobilization, and especially by the Sadat regime in an attempt to weaken and eliminate the Nasserite social base, became the dominant cultural paradigm. Researchers deemed too secular and critical of the religious discourses risked harassment, persecution, and even worse from the Islamic militants. The assassination of intellectuals by religious fundamentalists in Algeria shows the deadly face of intolerance, not from the state, but from civil society.

Religious fundamentalism is not peculiar to Islam. Indeed, as Khan shows in his highly textured analysis of Algerian intellectuals, during the brilliant classical phase of Islamic civilization, intellectual freedom flourished, before scholasticism developed and Islam became a handmaiden of Turkish domination. Later under French rule efforts were made to crush that freedom. The new intellectual strata created by colonialism was divorced from the masses, and as the lights of nationalism began to dim with time and under the cloud of a failing modernization, Islamic fundamentalistsmoved to occupy "thejagged cracks betweenidentity and modernity, consensusand democracy, authority and legitimacy"(p. 295).

Khan's paper underscores the need for more nuanced historical analysis and demonstrates that Mamdani's and Mafeje's assumptions that African intellectuals are a product of the colonial or postcolonial periods is not applicable to Africa as a whole. Nor is it even true of that concoction known as sub-Saharan Africa, as Diouf's paper, perhaps the best in the collection, amply demonstrates. Tracing the changing relations between intellectuals and the state in Senegal from the days of the great Sudanic empires to the present, Diouf shows that the intellectual strata created by the colonial state existed alongside a much older indigenous one, which colonialism unsuccessfully sought to domesticate and neutralize. The colonial intellectuals were tied to the fortunes of state capital and its developmentalist ambitions, notwithstanding their flirtation with the seemingly opposed ideologies of Senghor's negritude, Diop's NeoPhaoronism, and Marxism. As the crisis of modernization became more apparent, they sought refuge in the pretentions of technocratic solutions, thereby weakening their ability to contest structural adjustment programs in the politicized terrain of national politics, now increasingly filled by the intellectuals from the pre-colonial tradition who "have moved increasingly into the modern economic sector" and now "occupy a central position in all possible strategies in Senegalese society, because they are perfectly articulate in French, Wolof and Arabic, smoothly skilled in operating simultaneously in all the codes and in the milieux associated with them" (p.239).Thus what is described as the fragmentation of the intellectuals, refers to the modern school of intellectuals who have been less successful in determining their fate. Hence, they are now "falling back on a more professional definition of their role, with a consequent distancing from the state" (p.241). Their struggle for academic freedom, therefore, represents not simply a search for intellectual and institutional autonomy, but also a new self-image and mission.

Finally, in section five, there are two interesting pieces on the intellectual and legal struggles for academic freedom among Tanzanian and Senegaleseuniversity teachers. And in the appendix, Oloka-Onyango's rapporteur's summary brings alive the intellectual and emotional intensity of the conference deliberations and the unsparing self-criticism among the participants. For me this poignantly captured the new mood of self-confidence among African intellectuals, which bodes well for the future. Also included is The Kampala Declaration on IntellectualFreedom and Social Responsibility, in which intellectual rights and social responsibilities are deftly combined. 